胸部食道粘膜下層癌の悪性度に関する臨床病理学的検討

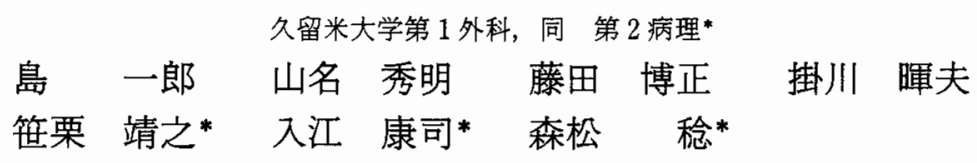

食道粘膜下層癌 (以下 sm 癌) の悪性度を, sm 層への浸潤度, 発育浸潤形式, matrix metalloproteinase-2(MMP-2)の発現より検討した. 対象症例は31例で, 1) 浸潤度 (sm1：6例, sm2： 15例， sm3：10例)では, sm3の $80 \%$ が0-I 型, sm1では癌肉腫を除き全例0-IIa 型であった。また, sm3 に $\mathrm{n}(+), \mathrm{ly} \cdot \mathrm{v}$, 再発が多かった. 2) 発育形式(下方発育型：13例, 表層発育型：8 例, 混合型 $: 10$ 例)では，下方発育型に0-I 型が，表層発育型に0-IIa 型が多かった。 $\mathrm{n}(+)$ は下方発育型と混合型に， $\mathrm{v}(+)$ と再発は表層発育型に多かった。 浸潤形式 (G1：4 例, G2：12例, G3：10例, G4C：4 例, G4D：1例）では，G3以上に0-I 型が多く, $\mathrm{n}(+)$ 頻度も高かった。 3）MMP-2発現を9例（29\%） に認め, $1 \mathrm{y}(+)$ と再発が多かった. 以上より，1）0-I 型は高度 sm 浸潤, 下方発育型, G3以上が多く, $\mathrm{n}(+), \mathrm{y} \cdot \mathrm{v}$ も高頻度で, 進行癌に準じた郭清が必要である，2）sm2以下でも表層発育型や MMP-2 発現例は再発が多く, 強力な合併療法と厳重な経過観察が必要である.

Key words: superficial esophageal carcinoma, matrix metalloproteinase-2, type IV collagenase

はじめに

食道粘膜下層漫潤癌) (以下 $\mathrm{sm}$ 癌と略す) は表在癌 であるが，その予後は他の消化管癌と比較して不良で あり 2)3)，満足すべき結果は得られていない.そこでわ れわれは, sm 癌の生物学的悪性度をリンパ節転移, 脈 管侵襲, 再発を指標として, 癌の sm 層への浸潤度, 発 育浸潤形式, さらに基底膜を破壊し, 癌の浸潤転移に 関与するとされる matrix metalloproteinase-2（以下 MMP-2）の発現の有無より検討し, sm 癌の病理組織 学的見地からみた悪性度診断とともに，その外科的治 療方針に関して考察したので報告する。

\section{対象と方法}

1980 1991年 2 月までに当科で切除した食道癌症例 は401例で，sm癌は35例（9\%）であった。このうち 術前未治療で, 食道の全割病理組織の検索を施行した 31例を対象とした（Table 1).

sm 癌を，1）sm 層への浸潤度，2）発育浸潤形式, 3）MMP-2の発現より分類し, 癌腫の肉眼型と病理組 織学的見地からみた生物学的悪性度（以下，悪性度) について検討を行った，食道癌の肉眼型は新分類案4

$<1992$ 年 2 月 12 日受理 $>$ 別刷請求先：島 一郎 ₹ 830 久留米市旭町 67 久留米大学医学部第 1 外科
Table 1 Clinical review of 31 patients with submucosal invasion of esophageal carcinoma

$\begin{array}{ll}\text { Sex } & \text { Men : Women }=28: 3 \\ \text { Age } & 60.4 \pm 9.9(38-86) \text { yrs }\end{array}$

\begin{tabular}{|c|c|c|c|}
\hline \multicolumn{2}{|l|}{ Site } & \multicolumn{2}{|c|}{ Histologic stage" } \\
\hline lu & 3 & 0 & 21 \\
\hline Im & 16 & II & 3 \\
\hline $\mathrm{Ei}$ & 11 & III & 5 \\
\hline $\mathrm{Ea}$ & 1 & IV & 2 \\
\hline Total & 31 cases & Total & 31 cases \\
\hline
\end{tabular}

に基づき, 悪性度の指標としては, リンパ節転移, 脈 管侵襲，再発の有無を用いた。なお，脈管侵襲の有無 はHE 染色および elastica-Van Gieson (EVG) 染色 標本を参考として判定した。統計学的解析は $\chi^{2}$ 検定を 用い， $\mathrm{p}<0.05$ を有意差ありとした。

1) $\mathrm{sm}$ 層への癌浸潤度：粘膜下層 $(\mathrm{sm})$ を 3 等分し, 癌の浸潤が粘膜筋板を越えるが $\mathrm{sm}$ の上 $1 / 3$ にどを るものを $\mathrm{sm} 1, \mathrm{sm}$ の $1 / 3$ むでにとどまるすのを sm2，それ以上であるが固有筋層には浸潤していない ものを $\mathrm{sm} 3$ とた。

2) 発育漫潤形式：発育形式は, 腫瘍面㺓 $(T)$ と sm 浸潤面積 $(\mathrm{Tsm})$ を算出して Tsm/T を求め, 0.2 以上 
を下方発育型， 0.2 未満で腫瘍長径が $3 \mathrm{~cm}$ を越える のを表層発育型, 上記以外を混合型と便宜上規定した。 浸潤形成は山本・小浜の分類 ${ }^{516)}$ に準じ，腫瘍境界が明 瞭で, 膨張性に発育する G1, 境界がやや不明瞭となっ た $\mathrm{G} 2$, 境界が不明瞭で小型の癌胞巣を形成し浸潤する G3, 癌胞巣がさらに小型で索状に浸潤する G4C, 癌胞 巣を形成せずびまん性に浸潤する G4D とした。

3) MMP-2の発現

パラフィン包埋切片を用い， ABC 法"7にて MMP-2 の免疫組織学的検索を行った。脱パラフィン後, $0.3 \%$ $\mathrm{H}_{2} \mathrm{O}_{2}$ 水溶液にて内因性ペルオキシダーゼ反応を阻害, さらにブロッキング用血清（ウサギ正常血清）で20分 間反底させ，非特異的反応を阻止した，抗ヒトMMP. 2ポリクローナル抗体は, ヒトリウマチ滑膜細胞より抽 出，精製した proMMP-2をヒッジに免疫化して作成 ( ${ }^{8)}$, 燐酸緩衝液で 400 倍希橎後, $4{ }^{\circ} \mathrm{C}$ に一一晚反応さ せた. 次にビオチン化ウサギ抗ヒッジ IgG と60分間, 続いて $\mathrm{ABC}$ 試薬 (Vector 社) と60分間反応させた $\mathrm{ABC}$ 試薬(Vector 社)と60分反応させた. 発色は DAB にて行い, ヘマトキシリン液で核染色した. MMP-2の

Table 2 Clinicopathological findings of 10 patients with lymphnode metastasis

\begin{tabular}{|c|c|c|c|c|c|c|c|}
\hline Case & Site" & $\begin{array}{l}\text { Histologic } \\
\text { type* }\end{array}$ & $\begin{array}{l}\text { Vascular } \\
\text { invasion }\end{array}$ & $\begin{array}{l}\text { Submucosal } \\
\text { invasion }^{\text {b) }}\end{array}$ & $\begin{array}{l}\text { Growth } \\
\text { pattern' }\end{array}$ & $\begin{array}{l}\text { Mode of } \\
\text { invasion }\end{array}$ & $\begin{array}{l}\text { Expression } \\
\text { of MMP-2 }\end{array}$ \\
\hline 1 & Im & carcinosarcoma & $\mid y(+) v(-)$ & $\mathrm{sm1}$ & Comb & G2 & - \\
\hline 2 & $\mathrm{Im}$ & mode & $\operatorname{ly}(-) \times(-)$ & sm1 & Down & $\mathrm{G} 2$ & - \\
\hline 3 & im & mode & $\operatorname{ly}(+) v(+)$ & sm2 & Super & G1 & + \\
\hline 4 & $\operatorname{lm}$ & mode & $\operatorname{ly}(-) v(-)$ & sm2 & Comb & G2 & - \\
\hline 5 & Ea & mode & $\mid y(+) v(-)$ & sm2 & Comb & G4C & - \\
\hline 6 & $\mathrm{Im}$ & mode & $\mid y(+) v(-)$ & sm3 & Comb & $\mathrm{G} 2$ & - \\
\hline 7 & Im & well & $\mid y(+) v(t)$ & $\mathrm{sm} 3$ & Down & G3 & + \\
\hline 8 & lu & mode & $\operatorname{ly}(+) v(-)$ & sm3 & Down & G3 & + \\
\hline 9 & $\mathrm{im}$ & well & ly $(+) v(t)$ & sm3 & Comb & G3 & - \\
\hline 10 & lu & poor & $\operatorname{ly}(+) v(+)$ & sm3 & Down & $\mathrm{G} 4 \mathrm{C}$ & - \\
\hline
\end{tabular}

発現は癌胞巣が明瞭に染色された場合を陽性と判定し た。

\section{結 果}

リンパ節転移は10例（33\%）に認められた（Table 2). 転移リンパ節は上縦隔と 1 群リンパ節に多く認め たが，なかでも右最上部リンパ節に 4 例，左最上部リ ンパ節に 1 例と, 転移リンパ節の半数は反回神経沿線 部への転移であった。術後再発は 5 例（16\%）に認め られ, リンパ節再発が 3 例, 他藏器再発は 2 例であっ た(Table 3). なお, sm 浸潤度, 発育漫潤形式, MMP. 2発現と覀性度との間には統計学的に有意な相関は認 められなかった。

1） $\mathrm{sm}$ 浸潤度と肉眼型および悪性度

sm1は 6 例, sm2は15例, sm3は10例であった. sm 浸 潤度と肉眼型との関係を文ると, sm3では0-Ip 型 3 例, 0-Ipl 型 4 例，0-Isep 型 1 例で，0-I 型が80\%を占めた。 一方, sm1では, 癌肉腫の 2 例を除けばすべて0-IIa 型 であった，sm2では0-I 型，0-IIa 型がほぼ半数ずつで あった（Table 4).

$\mathrm{sm}$ 浸潤度とリンパ節転移との関係では $\mathrm{sm} 1$ のリン パ節転移は33\%（2/6）であったが, sm3では50\%（5/ 10)にリンパ節転移を認めた。脈管侵襲は，sm 癌全体 では1y（十）が55\%，v（十）が45\%であった。 sm浸 潤度別にみると，sm1では ly（十，v（十）はそれぞ れ33\%, 17\%, sm2では $47 \%, 40 \%, \operatorname{sm} 3$ では $80 \%, 70 \%$ と，sm 浸潤度が高度になるほど脈管侵襲は増加した。 再発の 3 例は sm3で, $\operatorname{sm} 1$ と $\operatorname{sm} 2$ は 1 例ずつであった (Table 5).

2）発育浸潤形式と肉眼型および悪性度

下方発育型13例, 表層発育型 8 例, 混合型10例であっ た。肉眼型は下方発育の10例 (77\%) が0.I型であった のに対し，表層発育型は全例0-IIa 型であった，混合型

Table 3 Clinicopathological findings of 5 patients with post-operative recurrence

\begin{tabular}{|c|c|c|c|c|c|c|c|c|c|}
\hline Case & Site & $\begin{array}{l}\text { Histologic } \\
\text { type a) }\end{array}$ & $\begin{array}{l}\text { Lymph node } \\
\text { metastases }^{\text {() }}\end{array}$ & $\begin{array}{l}\text { Vascular } \\
\text { invasion" }\end{array}$ & $\begin{array}{l}\text { Submucossal } \\
\text { invasion D) }\end{array}$ & $\begin{array}{l}\text { Growth } \\
\text { pattern }\end{array}$ & $\begin{array}{l}\text { Mode of } \\
\text { invasion") }\end{array}$ & $\begin{array}{l}\text { Experssion } \\
\text { of MMP-2 }\end{array}$ & Recurrence \\
\hline 1 & Im & well & - & $\mid y(-) v(+)$ & $\mathrm{sm1}$ & Super & G1 & - & lymph nodes \\
\hline 2 & Im & mode & - & $|y|+\mid v(+)$ & $\mathrm{sm} 2$ & Super & G3 & + & lymph nodes \\
\hline 3 & Im & mode & + & $\mid y(+) v(+)$ & $\operatorname{sm3}$ & Comb & G2 & - & lymph nodes \\
\hline 4 & $\mathrm{Ei}$ & mode & - & $\mid y(+) v(t)$ & sm3 & Down & G4c & + & Lung, Bone \\
\hline 5 & lu & mode & - & $\mid y(+) v(+)$ & sm3 & Super & G3 & + & Lung, Bone, Liver \\
\hline
\end{tabular}


Table 4 Relationship between the degree of submucosal invasion and the gross type

\begin{tabular}{|c|c|c|c|c|c|}
\hline \multirow{2}{*}{$\begin{array}{l}\text { Submucosal" } \\
\text { invasion }\end{array}$} & \multirow{2}{*}{$\begin{array}{l}\text { No. of } \\
\text { cases }\end{array}$} & \multirow[b]{2}{*}{$n(t)$} & \multicolumn{2}{|c|}{ Vascular invasion } & \multirow{2}{*}{ Recurrence } \\
\hline & & & $l y(+)$ & $v(+)$ & \\
\hline $\begin{array}{l}\mathrm{sm1} 1 \\
\mathrm{sm2} \\
\mathrm{sm3}\end{array}$ & $\begin{array}{r}6 \\
15 \\
10\end{array}$ & $\begin{array}{l}2(33) \\
3(20) \\
5(50)\end{array}$ & $\begin{array}{l}2(33) \\
7(47) \\
8(80)\end{array}$ & $\begin{array}{l}1(17) \\
6(40) \\
7(70)\end{array}$ & $\begin{array}{l}1(17) \\
1(7) \\
3(30)\end{array}$ \\
\hline Total & 31 & $10(32)$ & $17(55)$ & $14(45)$ & $5(16)$ \\
\hline
\end{tabular}

3. Subrucosal invasion was deccribed in Materials and Muthods.

Table 5 Relationship between the submucosal invasion and malignant parameters

\begin{tabular}{|c|c|c|c|}
\hline \multirow{2}{*}{$\begin{array}{l}\text { Gross* } \\
\text { Type }\end{array}$} & \multicolumn{3}{|c|}{ Growth pattern } \\
\hline & Down $(\%)$ & Super(\%) & Combined(\%) \\
\hline $\begin{array}{l}0 \text { - -lp } \\
0 \text {-|p| } \\
0-\mid s e p \\
0-\mid 1 a \\
0-\mid l b \\
0-\| 1 c \\
0-\| 1 \mid\end{array}$ & $\begin{array}{l}2(14) \\
7(54) \\
1(8) \\
1(8) \\
0(0) \\
1(8) \\
1(8)\end{array}$ & 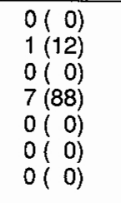 & $\begin{array}{l}5(50) \\
0(0) \\
1(10) \\
3(30) \\
0(0) \\
1(10) \\
0(0)\end{array}$ \\
\hline Total & 13 & 8 & 10 \\
\hline
\end{tabular}

Table 6 Relationship between the growth patterns and the gross type

\begin{tabular}{llll}
\hline \multirow{2}{*}{$\begin{array}{l}\text { Gross* } \\
\text { type }\end{array}$} & \multicolumn{3}{c}{ Submucosal invasion } \\
\cline { 2 - 4 } & $\mathrm{sm1}(\%)$ & $\mathrm{sm2}(\%)$ & $\mathrm{sm} 3(\%)$ \\
\hline $0-$ Ip & $2 *(33)$ & $2(13)$ & $3(30)$ \\
$0-$ Ipl & $0(0)$ & $4(27)$ & $4(40)$ \\
$0-$ Isep & $0(0)$ & $1^{\star *}(7)$ & $1(10)$ \\
$0-$ Ila & $4(67)$ & $6(40)$ & $1(10)$ \\
$0-$ Ilb & $0(0)$ & $0(0)$ & $0(0)$ \\
$0-$ Ilc & $0(0)$ & $2(13)$ & $0(0)$ \\
$0-$ III & $0(0)$ & $0(0)$ & $1(10)$ \\
\hline Total & 6 & 15 & 10 \\
\hline * carcinosarcoma * undifferentiated carcinoma \\
*New macroscopic classification superficial esophageal \\
carcinoma(draft) in Japan (1987. 6)
\end{tabular}

は0-I 型 6 例, 0-IIa 型 3 例, 0-IIc 型が 1 例であり, 0-I 型と0-II 型が約半数にみられた(Table 6).リンパ節転 移は混合型では 5 例 $(50 \%)$ ，下方発育型では 4 例 （31\%）にみられたが，表層発育型ではわずか 1 例 （13\%）のみであった. ly（十）は下方発育型, 表層発 育型，混合型のいずれにおいてもその頻度は50～60\% であった。一方，v（十）は下方発育型，混合型が $40 \%$ 前後であったのに対し，表層発育型では63\%と若干高 值を示した。また, 再発は, 表層発育型が 8 例中 3 例 （38\%）と高頻度に認められた（Table 7).

浸潤形式では G1が 4 例，G2が12例，G3が10例，G4
Table 7 Relationship between the growth patterns and malignant parameters

(\%)

\begin{tabular}{lccccc}
\hline $\begin{array}{l}\text { Growth } \\
\text { pattern }\end{array}$ & No. of & \multicolumn{4}{c}{ Vascular invasion } \\
\cline { 4 - 6 } cases & $n(+)$ & ly $(+)$ & $v(+)$ & \\
\hline Down & 13 & $4(31)$ & $7(54)$ & $5(38)$ & $1(8)$ \\
Super & 8 & $1(13)$ & $4(50)$ & $5(63)$ & $3(38)$ \\
Combined & 10 & $5(50)$ & $6(60)$ & $4(40)$ & $1(10)$ \\
\hline \multicolumn{5}{c}{ Down : Down growh type ; Super : Superficial growth type ; Comb : Combined type }
\end{tabular}

Table 8 Relationship between the mode of inva. sion and the gross type

\begin{tabular}{|c|c|c|c|c|c|}
\hline \multirow{2}{*}{$\begin{array}{l}\text { Gross } \\
\text { type }\end{array}$} & \multicolumn{5}{|c|}{ Mode of invasion ${ }^{6)}$} \\
\hline & G1 (\%) & $\mathrm{G} 2(\%)$ & G3 (\%) & $\mathrm{G} 4 \mathrm{c}(\%)$ & G4D (\%) \\
\hline $\begin{array}{l}0-1 p \\
0-1 p \mid \\
0-1 s e p \\
0-11 a \\
0-11 b \\
0-11 \mathrm{c} \\
0-111\end{array}$ & $\begin{array}{l}1(25) \\
0(0) \\
0(0) \\
3(75) \\
0(0) \\
0(0) \\
0(0)\end{array}$ & $\begin{array}{l}3(25) \\
3(25) \\
0(0) \\
4(33) \\
0(0) \\
2(17) \\
0(0)\end{array}$ & $\begin{array}{l}2(20) \\
3(30) \\
2(20) \\
3(30) \\
0(0) \\
0(0) \\
0(0)\end{array}$ & $\begin{array}{l}1(25) \\
1(25) \\
0(0) \\
1(25) \\
0(0) \\
0(0) \\
1(25)\end{array}$ & 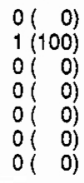 \\
\hline Total & 4 & 12 & 10 & 4 & 1 \\
\hline $\begin{array}{l}\text { G1 : w } \\
\text { G3: } \\
\text { G4D : } \\
\text { a) Nev } \\
\text { in } \\
\text { b) } \mathrm{moc}\end{array}$ & $\begin{array}{l}\text { so invasion } \\
\text { lacroscopic } \\
\text { an (1987. 6) } \\
\text { of invasion a }\end{array}$ & $\begin{array}{l}\text { ine; } G 2 \text { : le } \\
e ; G 4 c: \text { dif } \\
\text { scirrhous ty } \\
\text { ssification } s \\
\text { ording to } Y a\end{array}$ & $\begin{array}{l}\text { s, marked b } \\
\text { use invasion } \\
\text { perficial eso } \\
\text { namoto and }\end{array}$ & $\begin{array}{l}\text { orderline } \\
\text { of cord-like ty } \\
\text { phageal carcin } \\
\text { Kohama }\end{array}$ & $\begin{array}{l}\text { ype } \\
\text { noma (draft) }\end{array}$ \\
\hline
\end{tabular}

Table 9 Relationship between the mode of inva. sion and malignant parameters

\begin{tabular}{|c|c|c|c|c|c|}
\hline \multirow{2}{*}{$\begin{array}{l}\text { Mode of } \\
\text { invasion }\end{array}$} & \multirow{2}{*}{$\begin{array}{l}\text { No. of } \\
\text { cases }\end{array}$} & \multirow[b]{2}{*}{$n(+)$} & \multicolumn{2}{|c|}{ Vascular invasion } & \multirow{2}{*}{ - Recurrence } \\
\hline & & & $\mid y(+)$ & $V(+)$ & \\
\hline G1 & 4 & $1(25)$ & $1(25)$ & $2(50)$ & $1(25)$ \\
\hline G2 & 12 & $3(25)$ & $5(42)$ & $5(42)$ & $1(8)$ \\
\hline G3 & 10 & $4(40)$ & $6(60)$ & $4(40)$ & $2(20)$ \\
\hline G4c & 4 & $1(25)$ & $4(100)$ & $3(75)$ & $1(25)$ \\
\hline G40 & 1 & $1(100)$ & $1(100)$ & $0(0)$ & $0(0)$ \\
\hline
\end{tabular}

$\mathrm{C}$ が 4 例, G4D が 1 例であった。肉眼型をみると G1で は0-IIa 型が多く, G2では0-I 型と0-IIa 型が約半数ず っ，G3以上では大半が0-I 型であった(Table 8).リン パ節転移は，非浸潤型である G1，G2にそれぞれ25\%の 頻度で認めたが, 浸潤型である G3以上の症例では $40 \%$ (6/15) にリンパ節転移を認めた。 $1 \mathrm{y}, \mathrm{v}$ に関しては浸 潤形式による差はなく，再発は G3以上が 3 例（20\%） とやや多くみられた（Table 9).

3）MMP-2の発現と肉眼型および覀性度

非癌部食道上皮の MMP-2発現は, 陰性もしくは基 底層から傍基底層がわずかに染色される程度であっ た。一方, 癌部では腫瘍発育先進部あるいは癌胞巣周 囲において MMP-2が明瞭に染色された（Fig. 1)。全 症例に括ける MMP-2発現頻度は29\%（9/31）であっ 
Fig. 1 The specimens obtained from resected esophageal carcinoma embedded in paraffin. The paraffin sections were stained with monospecific antibody against human matrix metalloprotainase-2 using $A B C$ method. $A$, normal esphageal epithelium was negative or faintly positive $(\times 100)$. B, esophageal carcinoma with negative $(\times 100)$. C, esophageal carcinoma with moderately positive $(\times 100)$. D, esophageal carcinoma with strongly positive $(\times 100)$.

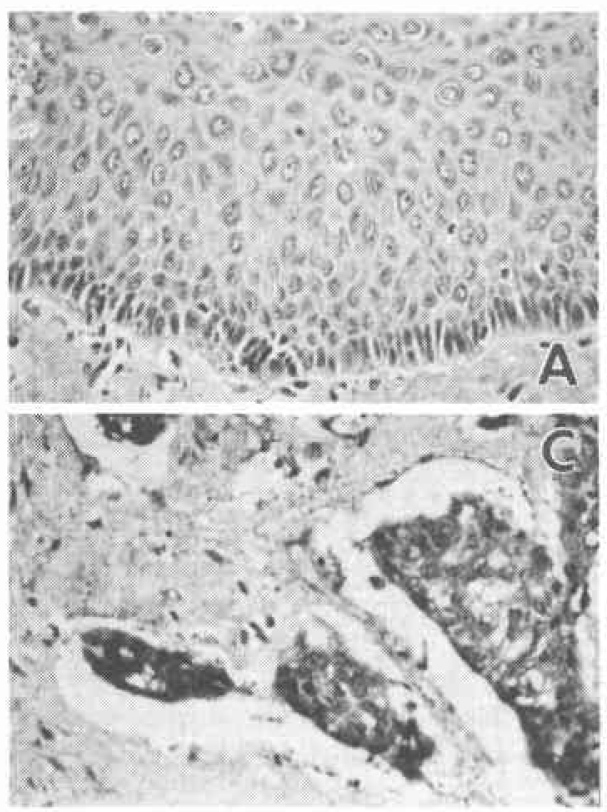

Table 10 Relationship between the expression of MMP-2 and the gross type

\begin{tabular}{|c|c|c|}
\hline \multirow{2}{*}{$\begin{array}{l}\text { Gross* } \\
\text { type }\end{array}$} & \multicolumn{2}{|c|}{ Expression of MMP-2 } \\
\hline & Negative (\%) & Positive (\%) \\
\hline $\begin{array}{l}0-\mid p \\
0-|p| \\
0-\mid s e p \\
0-\mid l a \\
0-|1| b \\
0-|| c \\
0-|I|\end{array}$ & $\begin{array}{l}6(27) \\
6(27) \\
2(9.5) \\
6(27) \\
0(0) \\
2(9.5) \\
0(0)\end{array}$ & $\begin{array}{l}1(11) \\
2(22) \\
0(0) \\
5(56) \\
0(0) \\
0(0) \\
1(11)\end{array}$ \\
\hline Total & 22 & 9 \\
\hline
\end{tabular}

New macroscopic classification
(draft) in Japan (1987. 6)

た. 肉眼堅は0-I 型 3 例, 0-IIa 型 5 例, 0-III 型 1 例で, MMP-2の発現と肉眼型との間には一定の関係はみら れなかった（Table 10）．MMP-2発現例のリンパ節転 移, ly (+), v (+) はそれぞれ33\%，78\%，56\%で， ly (+)の頻度が高度であった。再発は 3 例 $(33 \%)$ に 認められたが，その内 2 例は他臓器再発であった (Table 11).

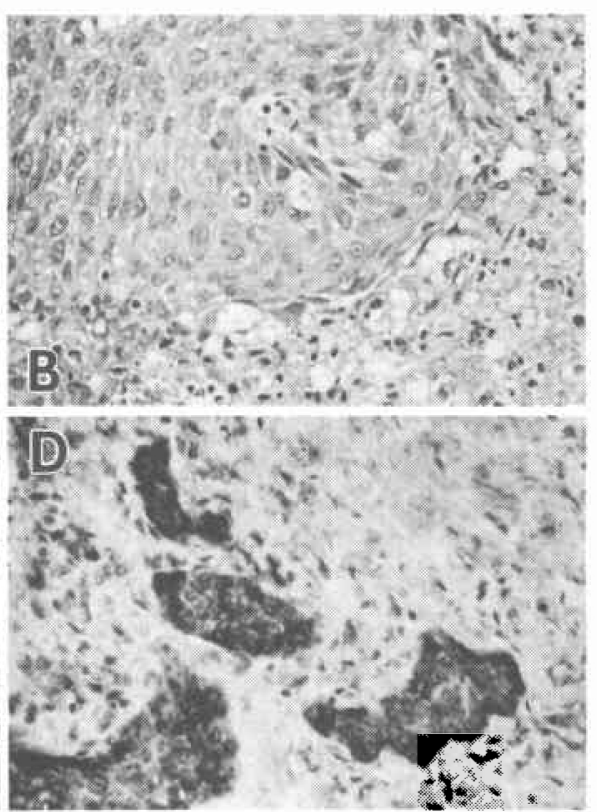

Table 11 Relationship between the expression of MMP-2 and malignant parameters

(\%)

\begin{tabular}{|c|c|c|c|c|c|}
\hline \multirow{2}{*}{$\begin{array}{l}\text { Expression } \\
\text { of MMP-2 }\end{array}$} & \multirow{2}{*}{$\begin{array}{l}\text { No. of } \\
\text { cases }\end{array}$} & \multirow[b]{2}{*}{$n(+)$} & \multicolumn{2}{|c|}{ Vascular invasion } & \multirow[b]{2}{*}{ Recurrence } \\
\hline & & & ly $(+)$ & $v(t)$ & \\
\hline Negative & 22 & $7(32)$ & $10(45)$ & $10(45)$ & $2(9)$ \\
\hline Positive & 9 & $3(33)$ & $7(78)$ & $5(56)$ & $3(33)$ \\
\hline
\end{tabular}

\section{考察}

食道 $\mathrm{sm}$ 癌は胃や大腸の $\mathrm{sm}$ 癌とは異なり,リンパ 節転移率は約 $30 \%$ にられ，その治療成績はきわめて 不良である ${ }^{9111}$ ，そこで食道の $\mathrm{sm}$ 癌は進行癌として 取り扱われるよらになり，拡大郭清が施行されるよう になってきた ${ }^{12)}$ にしかし，食道癌患者は高齢者が多く， 術前の全身状態は他の消化器癌に比べると比較的不良 であり，手術侵襲もきわめて高度であることから，sm に浸潤した症例のすべてを対象とし，進行癌に準じた 捘大郭清を行うことは, 若干の問題があると思われる。 そこでわれわれは，リンパ節転移，脈管侵襲，再発を 癌の生物学的悪性度の指標 ${ }^{13) 14}$ とし, 量的, 質的因子よ 
り sm 癌の特性について検討してみた。すなわち, 量的 因子として sm 層への癌浸潤度を，質的因子として発 育浸潤形式を，さらに機能的因子として癌の浸潤転移 に関与する proteinase の一つで, type IV collagenase とも呼ばれている MMP-215) 17)の発現について検索 した。

sm 層への癌浸潤度が高度になる汪どリンパ節転移 やly $(+) \cdot v(+)$ の頻度は増加し, 術後再発の頻度 をみても $\mathrm{sm} 1$ は 1 例のみで， 4 例は $\mathrm{sm} 2$ 以上であっ た．胃癌では sm 浸潤程度が高度になるほどリンパ節 転移や脈管侵襲頻度が高くなり，10年生存率も低下し たとの報告18)19)もあり，食道癌に拈いても $\mathrm{sm}$ 浸潤度 は重要な悪性度推定因子の一つと考えられた。また， 肉眼型でみると, sm1では0-IIa 型が, sm3では0-I 型が 大半を占め, 肉眼新分類は $\mathrm{sm}$ 浸潤度を良く反映して いるものと考えられた.

次に発育浸潤形式より検討した。われわれ Ohno $5^{201}$ の分類 (down growth type, spreading growth type, unclassified type) に準じて腫場面積と sm 浸潤 面積の比を求め, 垂直方向への発育が優位な下方発育 型, 水平方向への発育が優位な表層発育型(Ohno らは 腫瘍径を $2 \mathrm{~cm}$ 以上としているがわれわれは，腫瘍径が $3 \mathrm{~cm}$ 以上とした), 両者の混合型の 3 型に分類した. 深 部浸潤型は0-I 型が多く，表層発育型は0-IIa 型を呈す るものが多くみられた，悪性度との関係をみると混合 型，下方発育型ではりンパ節転移と ly $(+)$ が多くみ られた。表層発育型はリンパ節転移は少なかったが， $\mathrm{v}(+)$ と再発を多く認めた。 Ohno らは, down growth type は隆起型が多く,リンパ節転移, 脈管侵襲が高度 で予後は不良であったが, spreading growth type と unclassified type はリンパ節転䔟, 脈管侵襲が少なく 比較的予後が良好であったと報告している，われわれ の結果では, 下方発育型はOhno らと同様の傾向を認 めたにもかかわらず，表層発育型ではりンパ節転移は 少なかったものの $\mathrm{v}(+)$ と再発の頻度は高く, 彼らの 報告とは異なる結果を得た。この原因の一つとして, 設定条件の相違によることもあげられるが, Soga ら ${ }^{211}$ は表層進展型は比較的初期の病变でありながら予後不 良で，しかも血行性再発が多かったと報告しており， 表層型に関しては今後さらに検討が必要であ万う。

浸潤形式は山本・小浜の分類 ${ }^{6}$ に準じた。これは食道 癌取扱い規約》の増殖様式とINFを合わせたものと 考えられ, G1：膨張型で, INF $\alpha, \mathrm{G} 2$ : 中間型で, INF $\beta, \mathrm{G} 3$ 以上は浸潤型で, G3 : INF $\beta, \mathrm{G} 4 \mathrm{C}: \mathrm{INF} \gamma$,
G4D：硬癌，飞相当するすのと考光られる，山本ら ${ }^{6)}$ は，本分類は口腔の扁平上皮癌に打いて転移形成率や 手術成績と密接な関連があったと報告している，今回 検索した食道 $\mathrm{sm}$ 癌では，G3以上になると0-I 型が多 く，をた，リンパ節転移頻度が増加する傾向がみられ たが，有意なものではなかった。

以上ょり,下方発育型や G3以上の漫潤形式をとるも のは0-I 型が多く,これらはリンパ節転移頻度が高值を 示した. 一方, 表層拡大型は0-IIa 型が多く, $\mathrm{v}(+)$ や 再発をきたす頻度が高いため, 強力かつ有効な合併療 法の必要性が示唆された。

最後にMMP-2との関係について考察してみる. MMP-2 とは type IV collagenase とも呼ばれ，基底膜 の主要構成成分である type IV collagen を分解し，癌 の浸潤転移に関与寸ることが知られている22123). そこ でポリクローナル抗体を用いて MMP-2の発現を免疫 組織化学的に検索してみた.MMP-2の発現と悪性度と の間には有意な相関関係はみられなかったが，MMP2発現例では $\mathrm{y}(+)$ を $78 \%$ に認めた。 また，再発率は

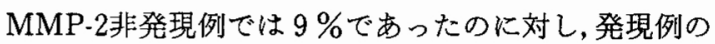
それは $33 \%$ と高く,MMP-2は脈管侵襲や再発の推定因 子となりらる可能性があるものと考えられた。

以上より，いわゆる悪性度が高い sm 癌とは, 肉眼型 では0-I 型を呈し, 組織学的には sm 浸潤度が高度で, 下方発育型あるいは混合型の発育をし, G3以上の浸潤 形式を示す type であり,このような症例ではリンパ節 転移や脈管侵襲の頻度が高く，進行癌に準じた切除郭 清術が必要であると考学る。また， 0-IIa 型で sm 浸潤 度が比較的浅くとも，表層発育型や MMP-2発現例で は術後の血行性再発率が高く, 有効な合併療法を加味 する必要があるものと考觉られる。一方, sm1はリンパ 節転移や脈管侵襲, さらには再発も少なく, 比較的悪 性度の低い腫場と考兄られた。今後の術前䛦断技術や 機器の向上により,リンパ節転移の有無や, sm1 と sm2 以上との鑑別が確実に判定されるようになれば， sm1 に対しては縮小手術が適応となる可能性も十分にあ り，より合理的な外科的治療が施行されるすのと考光 られる。

なお，本文の要旨は第44回日本胸部外科学会総会 (京都) にて発表した。

\section{文献}

1）食道疾患研究会編：臨床・病理。食道癌取扱い規 約. 金原出版, 東京, 1989

2）遠藤光夫, 山田明義, 井手博子：食道における早期 
癌治療の問題点. 日外会誌 $86: 1075-1078,1985$

3）三富利夫, 幕内博康, 生越喬二ほ如：早期食道癌の 治療。外科治療 $53 ： 587-591,1985$

4）板橋正幸, 廣田映五: 肉眼分類の解説（1）表在型 食道癌。胃之腸 $24: 471-475,1989$

5) Jacobson PA, Eneroth GM, Killander D et al : Histologic classification and grading of malignancy in carcnoma of the larynx. Acta Radiol $12: 1-7,1973$

6) Yamamoto E, Kohama G, Sunakawa $\mathrm{H}$ et al : Mode of invasion, bleomysin sensitivity, and clinical course in squamous cell carcinoma of the oral cavity. Cancer $51: 2175-2180,1983$

7) Hsu SM, Raine L, Fanger $H$ : The use of avidin-biotin-peroxidase complex $(A B C)$ in immunoperoxidase technique: A comparison between $\mathrm{ABC}$ and unlabeled antibody (PAP) procedures. J Histochem Cytochem 29: 577-580, 1981

8) Okada Y, Nagase H, Harris ED Jr : A metalloproteinase from rheumatoid synovial fibroblast that digests connective tissue matrix components. Purification and characterization. J Biol Chem 26:1425-14255, 1986

9）五関謹秀, 小池盛雄, 滝澤登一郎ほか：現行の早期 食道癌定義上の問題点. 食道表在癌といわゆる早 期胃癌及び pm 胃癌との病理組織学的比較検討. 胃之腸 22：14429-1436, 1987

10）吉野肇一, 平畑 忍, 片井均仼か：早期胃癌に対 する縮小手術の妥当性. 一手術成績, 再発形式, 診 断能力などからみて一. 日外会誌 89 : $1509-1512,1988$

11）松本好市, 石島直人, 菅谷義範ほか：直腸粘膜下層 癌の臨床病理学的検討. 一固有筋まで浸潤した癌 と比較して一. 日済外会誌 $22: 1127-1132,1989$

12) Kato H, Tachimori $Y$, Watanabe $H$ et al: Superficial esophageal carcinoma. Surgical treatment and the results. Cancer $66 \quad$ : 2319-
2323, 1990

13）井出博子, 遠藤光夫, 木下裕宏ほか：手術所見及び 予後からみた食道癌 $\mathrm{m}, \mathrm{sm}$ 癌の治療方針。外科診 療 $22: 1659-1666,1980$

14）鍋谷欣市：食道癌をめぐる臨床的考察. 日消外会 誌 $1: 769-778,1988$

15) Liotta LA, Rao CN, Barksy $\mathrm{SH}$; Tumor invasion and the extracellualr matrix. Lab Invest $49: 636-649,1983$

16) Liotta LA: Tumor invasion and metastasis. -Role of extracelluar matrix-. Cancer Res 46:1-7, 1986

17) Yamagata $S$, Ito $Y$, Tanaka $R$ et al: Gelatinases of metastatic cell lines of murine colonic carcinoma as detected by substrate-gel electrophoresis. Biochem Biophys Res Commun $151: 158-162,1988$

18）坂本啓介, 秋山洋, 豊島範夫洁か：早期胃癌の予 後を左右する因子一特に粘膜下浸潤と予後の関係 について一. 手術 26:267-273, 1972

19）宮本幸男，大和田進，棚橋美文ほか：粘膜下層 (sm) 浸潤胃癌の臨床病理学的検討. 日臨外医会誌 $48: 584-588,1987$

20) Ohno S, Mori M, Tsutsui S et al: Growth patterns and prognosis of submucosal carcinoma of the esophagus. A pathological study. Cancer $68: 335-340,1991$

21) Soga J, Tanaka O, Sasaki K et al: Superficial spreading carcinoma of the esophagus. Cancer $50: 1641-1645,1982$

22) Liotta LA, Thorgeirsson UP, Garbisa S: Role of collagenases in tumor cell invasion. Cancer Metastasis Rev 1:277-288, 1982

23) Salo $T$, Liotta LA, Tryggvasion K : Purificaton and characterization of murine basement membrane collagen-degrading enzymes secreted by metastatic tumor cells. J Biol Chem 258:2058-2062, 1983

\title{
Clinicopathological Analysis of Esophageal Carcinoma with Submucosal Invasion
}

\author{
Ichiro Shima, Hideaki Yamana, Hiromasa Fujita, Teruo Kakegawa, Yasuyuki Sasaguri*, \\ Koji Irie* and Minoru Morimatsu* \\ The First Department of Surgery and Second Department of Pathology*, \\ Kurume University School of Medicine
}

Thiryteen-one cases of esophageal carcinoma invading the submucosal were analyzed regarding the degree of submucosal invasion, the growth patterns, the mode of invasion, and the expression of matrix metalloproteinase-2 (MMP-2). For the degree of submucosal invasion, the deeply invading type (sm3: 10 cases) was characterized by a tendency toward the superficial and protruding type (type 0-1), a high incidence of lymph node metastasis, vascular invasion, and post-operative recurrence. In contrast, the slightly invading type (sm1: 6 cases) was characterized by 
the slightly elevated type (type 0-IIa), a low incidence of lymph node metastasis, vascular invasion, and recurrence. For the growth patterns, the majority of down growth type (13 cases) was in type 0-I, and this type was associated with lymph node metastasis, while, almost all of the superficial spreading type (8 cases) was in type 0-IIa, which was associated with blood vessel invasion and recurrence. On the other hand, in the mode of invasion, the group with diffuse invasion (G3, G4C, and G4D) had lymph node metastasis more frequently than the group with non-diffuse invasion (G1 and G2). In immunohistochemical staining, the expression of MMP-2 was detected in 9 (29\%) cases. Its expression, however, was not detected in non-cancerous esophageal epithelia. A good correlation was found among the expression of MMP-2, lymphatic invasion, and post-operative recurrence.

Reprint requests: Ichiro Shima The First Department of Surgery, Kurume University School of Medicine 67 Asahimachi, Kurume, 830 JAPAN 